\title{
1213 キャビテーションピーニングを施した鋼歯車の面圧強さ Surface Durability of Cavitation-Peened Steel Gear
}

\author{
○正 關 正憲(岡山大学) \\ 正 藤井 正浩 (岡山大学) \\ 西江 徳人 (岡山大学大学院)
}

\author{
正祖山均 (東北大学) \\ 飛田 芳希（(株）村田製作芹） \\ 正 吉田 彰 (広島国際大学)
}

\begin{abstract}
Masanori SEKI, Okayama University, 3-1-1, Tsushima-Naka, Okayama Hitoshi SOYAMA, Tohoku University, Aoba 6-6-01, Aramaki, Aoba-ku, Sendai Masahiro FUJII, Okayama University, 3-1-1, Tsushima-Naka, Okayama Yoshiki TOBITA, Murata Manufacturing Co., Ltd., 1-10-1, Higashikotari, Nagaokakyo-shi, Kyoto Naruto NISHIE, Graduate School of Okayama University, 3-1-1, Tsushima-Naka, Okayama Akira YOSHIDA, Hiroshima International University, 5-1-1, Hirokoshingai, Kure
\end{abstract}

In order to investigate the effect of cavitation peening on surface durability of steel gears, the case-hardened steel rollers and gears cavitation-peened under different conditions were fatigue-tested using a roller testing machine and a gear testing machine. The hardness and the compressive residual stress of the test rollers and gears were increased by the cavitation peening. On the other hand, their surface roughness was not increased so much. In the roller tests, the fatigue life of all the cavitation-peened rollers was longer than that of the non-peened roller. In the gear tests, the surface durability of the test pinions was improved by the cavitation peening. Judging from the relationships between the maximum stress amplitude and the surface roughness, it was clear that the surface durability of steel gears was improved by the increase in surface hardness due to the cavitation peening with little influence of surface roughness.

Key words: Gear, Fatigue, Cavitation, Peening, Surface Treatment, Steel, Strength, Hardness, Residual Stress, Surface Roughness

\section{1.緒言}

キャビテーションは，流体機械の性能劣化，壊食による固 体面の破壊，振動や騒音の発生などが悪影響として挙げられ る(1). キャビテーションによる壊食は，液体中に発生した多 数の気泡が固体面近くで崩壊する際に固体面に損傷を与え る現象(2)であるが，その崩壊圧力を有効利用したものの 1 つ がキャビテーションピーニング(3) (以下 $\mathrm{CP}$ と記す)である. CP はキャビテーション気泡を伴う高速水噴流（キャビテー ション噴流）を利用しており，剛体接触することなく，ピー ニングによる表面改質を実現することができる.

これまでに，炭素鋼やアルミニウム合金などの金属材料に 対し，CPによって圧縮残留応力が導入されたことが示され， そのうえ回転曲げ疲労強度が向上する結果が得られた ${ }^{(4),(5)}$. さらには, $\mathrm{X}$ 線回折の強度分布の半価幅が $\mathrm{CP}$ によって減少 すること ${ }^{(0)}$ ，ピーニングにより曲面を成形するピーンフォー ミングが CP によって実現できること(7)，シリコンウエハの ゲッタリングに CP が有効利用できること ${ }^{(8)}$ などが実証され ている.

そこで本研究では，機械要素の強度向上に対する $\mathrm{CP}$ の応 用として，鋼歯車の面圧強さに及ぼす $\mathrm{CP}$ の影響について検 討を行った。

\section{2. ローラと歯車}

$2 \cdot 1$ ローラと㐘車の製作 表 1 に本研究で用いたロー ラと歯車の製作条件を示す. 試験ローラ対は直径 $60 \mathrm{~mm}$ であ り，試験ローラはクロムモリブデン銅（JIS：SCM415）で製 作され，浸炭硬化（浸炭処理： $\mathrm{CO}^{2} 1.2 \mathrm{vol} \%$, C.P. $0.6 \mathrm{wt} \%$, $1193 \mathrm{~K} \times 5 \mathrm{~h}$, 焼入れ : $1073 \mathrm{~K} \times 0.5 \mathrm{~h}$, 油冷, 焼戻し: $473 \mathrm{~K} \times 3 \mathrm{~h}$, 空冷）の後, 研削仕上げされた. また, 本研究で用いた試験 歯車対はモジュール $5 \mathrm{~mm}$, 基準圧力角 $20^{\circ}$ ，歯数 20/21 であ り，クロムモリブデン鋼（JIS：SCM415）で製作され，浸炭 硬化の後, 研削仕上げが施された。ここで，浸炭硬化ローラ ならびに浸炭硬化歯車の表記名をそれぞれ R， G とする。な
お，相手ローラと相手歯車にはクロムモリブデン鋼を機械加 エし，浸炭硬化ならびに研削仕上げしたものを用いた。

Table 1 Manufacturing conditions of rollers and gears

\begin{tabular}{c|c|c|c|c}
\hline & Test roller & Mating roller & Test pinion & Mating gear \\
\hline Specimen & $\mathrm{R}$ & $\mathrm{RM}$ & $\mathrm{G}$ & $\mathrm{GM}$ \\
\hline Material* & SCM415 & SCM420 & SCM415 \\
\hline Heat treatment & \multicolumn{4}{|c}{ Case hardening } \\
\hline Finishing & \multicolumn{4}{|c}{ Grinding } \\
\hline "JIS G 4105-1979
\end{tabular}

Table 2 Cavitation peening conditions for rollers and gears

\begin{tabular}{|c|c|c|c|c|}
\hline Condition name & NP & W1P3T3 & V2P3T01 & \\
\hline Injection type & 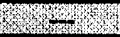 & \multicolumn{2}{|c|}{ Water } & \\
\hline Nozzle diameter & 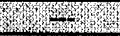 & $1 \mathrm{~mm}$ & $2 \mathrm{~mm}$ & \\
\hline Injection pressure & 8 & \multicolumn{2}{|c|}{$30 \mathrm{MPa}$} & \\
\hline Processing time & 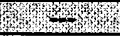 & $30 \mathrm{~min}$ & $1 \mathrm{~min}$ & \\
\hline Condition name & W2P3T02 & W2P3T05 & W2P3T1 & W2P3T3 \\
\hline Injection type & \multicolumn{4}{|c|}{ Water } \\
\hline Nozzle diameter & \multicolumn{4}{|c|}{$2 \mathrm{~mm}$} \\
\hline Injection pressure & \multicolumn{4}{|c|}{$30 \mathrm{MPa}$} \\
\hline Processing time & $2 \min$ & $5 \mathrm{~min}$ & $10 \mathrm{~min}$ & $30 \mathrm{~min}$ \\
\hline
\end{tabular}

$2 \cdot 2$ ローラと歯車に対するCP処理 表 2 に研削仕上 げ後のローラと歯車に施した CP 条件を示す. CPに用いるキ ヤビテーション噴流として, 水中で高速水噴流を噴射させる 水中キャビテーション噴流 ${ }^{(4)}$ と気中で高速水噴流および低速 水噴流を同時に噴射させる気中キャビテーション噴流(6)があ るが, 本研究では水中キャビテーション噴流を用いた，また， キャビテーション噴流を発生させるために 2 種類のノズル A と B を使用した.ノズル B は, より大きなピーニング効果が 得られるようにノズル A の先端形状を改良したものである. ノズル A を用いた場合は回転速度 60rpm, ノズル B を用いた 場合は回転速度 $20 \mathrm{rpm}$ でローラおよび歯車を回転させながら， ローラ円周面ならびに歯車歯面に CP を施した. ここで，試 験片表記名として，ノズル A を用いて W2P3T3 の条件で CP 
を施したローラを RA-W2P3T3 とした.また NP は CP を施し ていないことを示す. なお，相手歯車には A-W1P3T3 の条件 で CP を施し，相手ローラには CP を施していない.

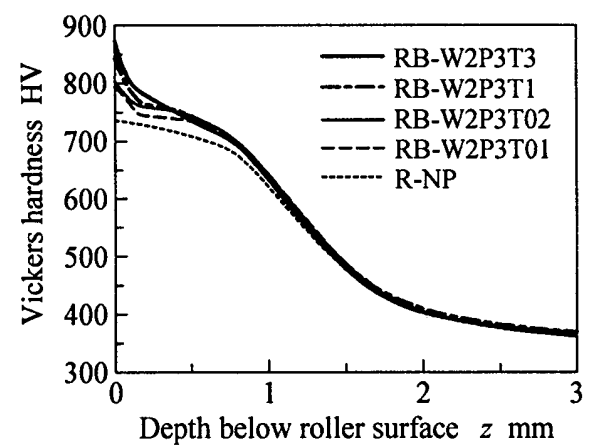

Fig.1 Hardness distributions of test rollers
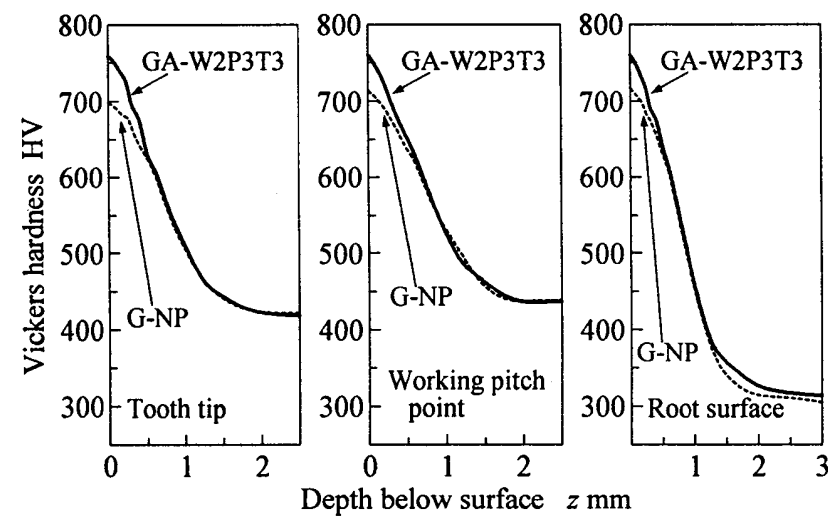

Fig.2 Hardness distributions of test pinions

$2 \cdot 3$ ローラと歯車の性状 図 1 にローラ円周面下の硬 さ分布を示す。マイクロビッカース硬度計を使用し，ローラ 軸断面においてローラ円周面からの深さ $z$ ごとに硬さ測定を 行った.この図より CP によってローラ円周面付近の硬さが 増加し, 特に CP の処理時間が長いほど硬さが増加する傾向 がみられる．また，CP による加工硬化層は，ローラ円周面 から梁さ約 $0.5 \mathrm{~mm}$ の範囲であり, ショットピーニングの場合 (9) と同程度であった。

図 2 は歯車表面下の硬さ分布を示したものである.歯先付 近，かみあいピッチ点付近，歯底面のそれぞれにおいて，歯 面または歯底面に対する垂直方向を深さ方向とし，歯車軸直 角断面で硬さ測定を行った.この図においてもローラの場合 と同様に CP によって歯車表面付近の硬さが増加しているこ とが確認できる. 歯先付近, かみあいピッチ点付近, 歯底面 のいずれの場所でも CP による硬さの増加がみられたことか ら，歯車などのような複雑形状の機械部品に対しても $\mathrm{CP}$ は 有効であると考えられる。

図 3 にローラ円周面下の残留応力分布を示す.残留応力は, 特性 X 線として $\mathrm{CrK} \alpha$ 線を用い， $2 \theta-\sin ^{2} \psi$ 法(10)によりローラ 円周面で測定を行った。 ローラ円周面下の残留応力測定では, 電解研磨によりローラ円周面を除去加工しながら，ローラ円 周面からの梁さ $z$ ごとに測定を行った. なお，ローラ円周面 におけるローラ軸方向, 円周方向, 半径方向をそれぞれ $x, y$, $z$ 軸とした. 図 3 より CPによってローラ円周面付近に圧縮残 留応力が付与されており, CP の処理時間 1 分より 30 分の方 が大きな圧縮残留応力が付与されている. CP による圧縮残 留応力の導入範囲は, 口ーラ円周面からの梁さ約 $0.2 \mathrm{~mm}$ の範 囲であり，圧縮残留応力層の範囲においてもショットピーニ ングの場合 ${ }^{(9)}$ と同程度であった。
表 3 と表 4 にそれぞれ試験ローラと試験歯車の表面性状を 示す.ここで表中の表面粗さ $R_{\mathrm{z}}$ は，ローラ円周面における口 一ラ軸方向, または歯車歯面のかみあいピッチ点付近におけ る歯形方向の表面粗さ（最大高さ） $R_{\mathrm{z}}$ である. また表面硬さ は，ローラ円周面下ならびに歯車歯面下の硬さ分布を近似し た際の梁さ $z=0.0 \mathrm{~mm}$ における硬さである. 表中の表面残留応 力 $\left(\sigma_{\mathrm{x}}\right)_{\mathrm{r}}$ は, 歯車歯面のかみあいピッチ点付近における歯筋方 向の残留忘力であり， $\left(\sigma_{\mathrm{y}}\right)_{\mathrm{r}}$ は，歯車歯面のかみあいピッチ点 付近における歯形方向の残留応力である.ローラの場合の残 留応力は先述のとおりである.

表 3 より，CP の処理時間が長くなるほど，ローラ円周面 における表面硬さならびに表面圧縮残留応力が増加する傾 向がみられる. また表 4 では，ノズル A を用いた場合より， 改良したノズル B を用いた CPによって歯車歯面の表面硬さ と表面圧縮残留応力が増加している. 一方, 表面粗さは CP を施してもほとんど変わらなかった。

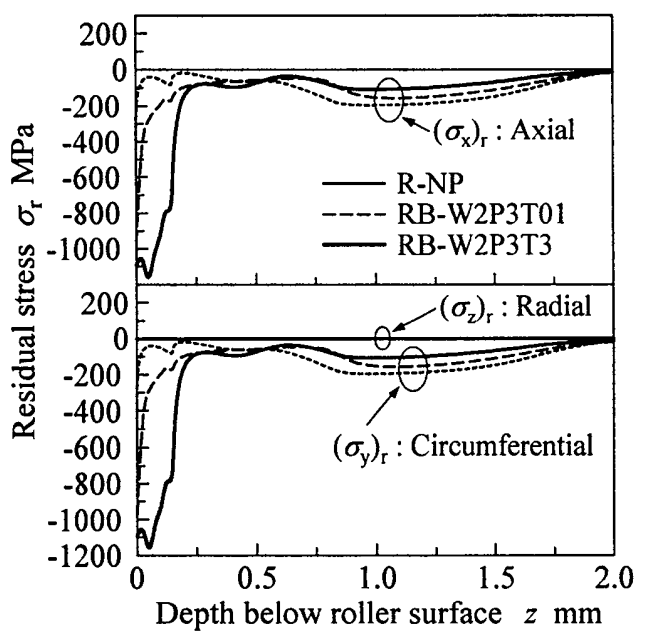

Fig.3 Residual stress distributions of test rollers

Table 3 Surface properties of test rollers

\begin{tabular}{|c|c|c|c|c|c|}
\hline Specimen & R-NP & $\begin{array}{c}\text { RB- } \\
\text { W2P3T01 }\end{array}$ & $\begin{array}{c}\text { RB- } \\
\text { W2P3T02 }\end{array}$ & $\begin{array}{c}\text { RB- } \\
\text { W2P3T1 }\end{array}$ & $\begin{array}{c}\text { RB- } \\
\text { W2P3T3 }\end{array}$ \\
\hline$R_{\mathrm{z}}, \mu \mathrm{m}$ & 317 & 2.08 & 2.59 & 3.08 & 3.61 \\
\hline HV & 737 & 793 & 804 & 844 & 874 \\
\hline$\left(\sigma_{\mathrm{x}}\right) \mathrm{MPa}$ & -375 & -969 & -1098 & -1187 & -1096 \\
\hline$\left(\sigma_{\mathrm{v}}\right)_{\mathrm{r}} \mathrm{MPa}$ & 164 & -234 & -504 & -672 & -759 \\
\hline
\end{tabular}

Table 4 Surface properties of test pinions

\begin{tabular}{|c|c|c|c|c|}
\hline Specimen & GNP & $\begin{array}{c}\text { GA- } \\
\text { W1P3T3 } \\
\end{array}$ & $\begin{array}{c}\text { GA- } \\
\text { W2P3T3 }\end{array}$ & $\begin{array}{c}\text { GB- } \\
\text { W2P3T05 }\end{array}$ \\
\hline$R_{z} \mu \mathrm{m}$ & 2.36 & 2.06 & 1.97 & 2.21 \\
\hline $\mathrm{HV}$ & 715 & 726 & 760 & 783 \\
\hline$\left(\sigma_{x}\right)_{1} \mathrm{MPa}$ & 385 & -675 & -474 & -661 \\
\hline$\left(\sigma_{\mathrm{v}}\right)_{\mathrm{r}} \mathrm{MPa}$ & -657 & -781 & -733 & -856 \\
\hline
\end{tabular}

図 4 に試験ローラの表面写真およびローラ.軸方向の粗さ曲 線, さらにその粗さ曲線を FFTによるスペクトル解析を行っ た結果を示す，表面写真はレーザ顕微鏡により撮影されたも のであり，スペクトル解析は前報 ${ }^{(11)}$ と同じ方法で行った. 図 中の表面写真より， $\mathrm{CP}$ を施しても研削痕をはっきりと観察 することができる. さらに, 表 3 と表 4 で示したように CP の有無に関わらず表面粗さの大きさがほとんど変わらない ことから，本研究で用いた試験片の表面粗さに及ぼす CP の 影響はかなり小さいと言える。

粗さ曲線のスペクトル解析結果をみると, R-NP と CP の処 理時間が短い RB-W2P3T01 ならびに RB-W2P3T02 では違い 
がみられなかった，一方， $1 / \lambda=20 \mathrm{~mm}^{-1}$ より大きな範囲，すな わち波長 $\lambda か ゙ 50 \mu \mathrm{m}$ より小さな範囲において, RB-W2P3T1 と RB-W2P3T3 のスペクトルが，R-NPに比べ相対的に少し小さ くなっている. 言い換えると, 本研究の範囲内で長い処理時

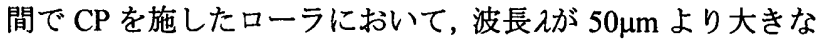
範囲のスペクトルが相対的に大きくなっている. これは表面 粗さ $R_{\mathrm{z}}$ を変化させない範囲内で, $\mathrm{CP}$ による塑性変形が $50 \mu \mathrm{m}$ より大きな波長入の範囲に現れたものであると考えられる. なお,アルミニウムに対して直径 $450 \mu \mathrm{m}$ の大きさの塑性変形 が CPによって生じたことが確認されている(12). 以上のこと から，ローラ円周面と歯車歯面にピーニング効果が付与され， 表面粗さに及ぼす $\mathrm{CP}$ の影響はかなり小さいことから, CPに よる鋼歯車の面圧強さ向上が期待できる。

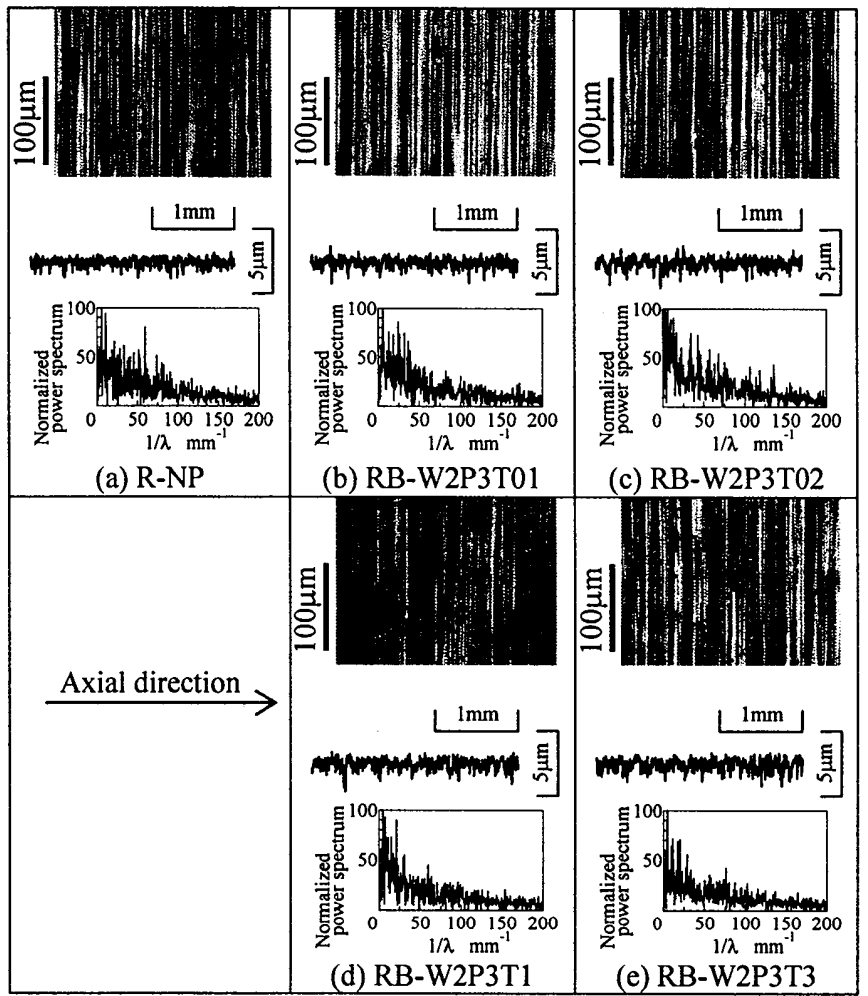

Fig.4 Surface photographs and roughness curves of test rollers

\section{3、試験方法と試験結果}

3・1 疲れ試験方法本研究では, ばね負荷式二円筒滑 り転がり疲れ試験機 ${ }^{(13)}$ を使用し, 試験ローラを低速側（ロー ラ周速度 $4.50 \mathrm{~m} / \mathrm{s}$, 滑り率 $-25.6 \%$ ), 相手ローラを高速側（口 一ラ周速度 $5.65 \mathrm{~m} / \mathrm{s}$ ，滑り率 $+20.4 \%$ ） としてローラの転がり 疲れ試験を行った. 歯車の運転疲れ試験では, FZG 型動力循 環式歯車試験機 (11)を用い, 試験歯車を被動側, 相手歯車を駆 動側として, 試験歯車の回転速度 $n_{1}=1800 \mathrm{rpm}$ で運転疲れ試 験を行った. 負荷の基準として，2つのローラ間または歯車 のかみあいピッチ点におけるへルツの最大接触応力 $p_{\max }{ }^{(14)}$ を用いた。 また潤滑油として，ローラの転がり疲れ試験では ATF（動粘度 $33.18 \mathrm{~mm}^{2} / \mathrm{s}$ [313K]，7.225 $\mathrm{mm}^{2} / \mathrm{s}$ [373K]）を使

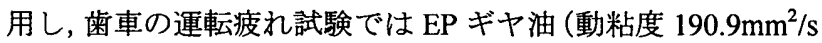
$\left.[313 \mathrm{~K}], 17.47 \mathrm{~mm}^{2} / \mathrm{s}[373 \mathrm{~K}]\right)$ を使用した. 試験ローラ対お よび試験歯車対への供給時の油温は $313 \pm 4 \mathrm{~K}$ に制御した。

ここで, ローラの転がり疲れ試験は $p_{\max }=2000 \mathrm{MPa}$ で行わ れ, Dowson の式(15)より求めた試験ローラ対の理論最小油膜 厚さ $h_{\min }$ は $1.7 \mu \mathrm{m}$ であった. 一方, 歯車の運転疲れ試験は $p_{\max }=1900 \mathrm{MPa} \sim 2300 \mathrm{MPa}$ の範囲で行われ， $h_{\min }=0.7 \mu \mathrm{m} \sim$
$1.7 \mu \mathrm{m}$ であった。 また，Dawson が定義した $D$ 值 ${ }^{(16)}$ は本研究 で用いたすべての試験ローラ対ならびに試験歯車対におい て $D>1$ であった.

本研究の疲れ試験では, 任意の試験ローラおよび試験歯車 繰返し数 $N_{1}$ ごとにローラ円周面または歯車歯面に生じたピ ッチングの面積を測定し, 試験ローラ対または試験歯車対の 総接触面積に対するピッチング面積の比で表すピッチング 面積率を求めた。 そのピッチング面積率が $5 \%$ に達したとき の試験ローラおよび試験歯車繰返し数をその疲れ寿命 $N$ と した. また，ローラの大きな損傷あるいは歯の折損により異 常振動が発生し, 振動感受スイッチによって試験機が自動停 止したときの試験ローラまたは試験歯車繰返し数も疲れ寿 命 $N$ とした.

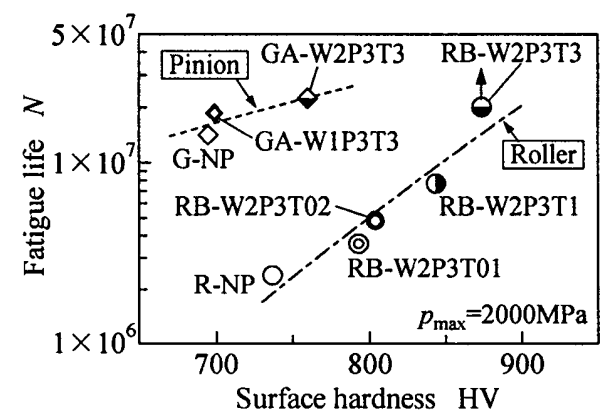

Fig.5 Relationships between fatigue life and surface hardness of test rollers and pinions

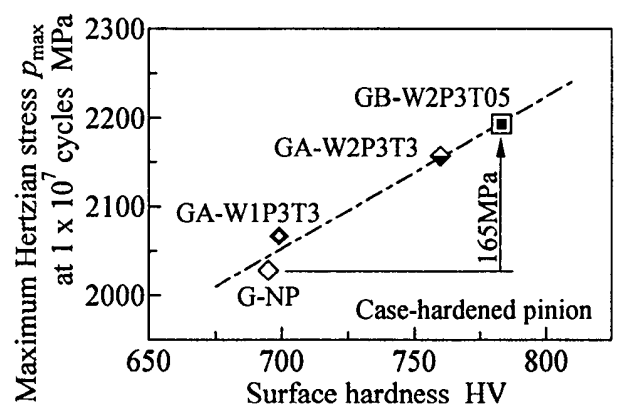

Fig.6 Relationships between surface durability and surface hardness of test pinions

$3 \cdot 2$ 試験ローラの疲れ寿命 ローラの転がり疲れ試験 により得られた試験ローラの疲れ寿命 $N$ と表 3 に示した表面 硬さの関係を図 5 に示す。ここで，ローラの損傷形態は表面 下き裂発生に起因するスポーリング損傷であり，その損傷深 さは, ローラ円周面から梁さ約 $0.5 \mathrm{~mm}$ までの範囲内であった. この図には $p_{\max }=2000 \mathrm{MPa}$ で行われた歯車の運転疲れ試験で 得られた試験歯車の疲れ寿命 $N$ も合わせて示す. なお, RB-W2P3T3 の矢印は, 繰返し数 $2 \times 10^{7}$ までに損傷しなかった ことを表している.

図 5 より，試験ローラと試験歯車の疲れ寿命が CP によっ て向上したことが確認できる，さらに，CP による硬さの増 加が大きいほど, 疲れ寿命が向上する傾向がみられた，転が り疲れ試験の場合 (17), 接触面における表面粗さの影響を受け, 疲れ寿命があまり向上しない，あるいは低下することがある が, CP による表面粗さの変化はあまりなかったことから， $\mathrm{CP}$ を施した試験ローラと試験歯車の疲れ寿命に及ぼす表面 粗さの影響はほとんどなかったと考えられる。

$3 \cdot 3$ 試験歯車の面圧強さ歯車の運転疲れ試験で得ら れた試験歯車の面圧強さと表 4 に示した表面硬さの関係を図 6 に示す. 本研究では, 疲れ寿命 $N=1 \times 10^{7}$ に対するへルツの 最大接触忘力 $p_{\max }$ を試験歯車の面圧強さとした. 試験歯車の 
主な損傷形態は，かみあいピッチ点付近での表面き裂発生に 起因するピッチング損傷であった.

図 6 より, 試験歯車の面圧強さが CPによって向上し, 特 に CP による硬さの増加が大きい試験歯車ほど，その面圧強 さが向上したことがわかる. 本研究の範囲内で最も面圧強さ が大きかった GB-W2P3T05 は, G-NPに比べ165MPa向上し, 約 $8 \%$ の疲労強度向上が CP によって得られている.

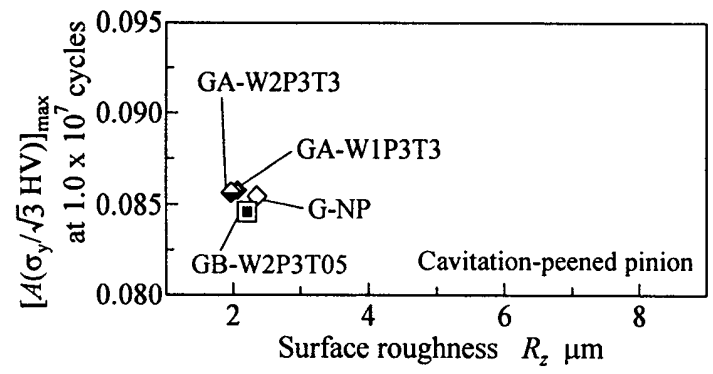

Fig.7 Relationships between maximum amplitude and surface roughness of cavitation-peened pinions

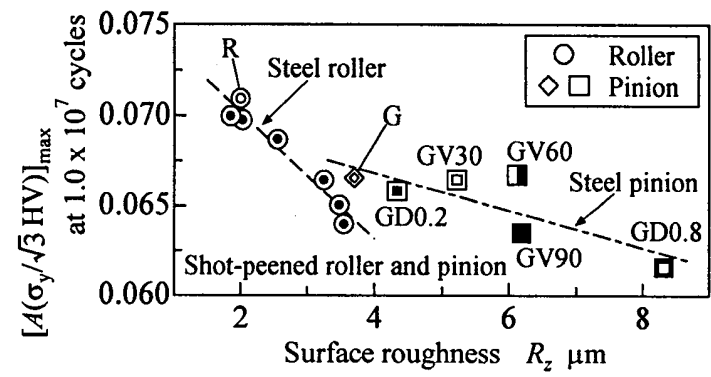

Fig.8 Relationships between maximum amplitude and surface roughness of shot-peened rollers and pinions

$3 \cdot 4$ 応力振幅と表面粗さの関係 前述のように本研究 で使用した試験歯車の損傷形態はピッチング損傷であった ことから，前報 ${ }^{(11)}$ と同様に垂直応力 $\sigma_{\mathrm{y}}$ を用い，疲れ寿命 $N=1 \times 10^{7}$ に対するへルツ忘力 $p_{\max }$ での各試験菌車の振幅最大 值 $\left[A\left(\sigma_{\mathrm{y}} / \sqrt{3} \mathrm{HV}\right)\right]_{\max }$ を求めた。図 7 はその振幅最大值 $\left[A\left(\sigma_{\mathrm{y}} / \sqrt{3} \mathrm{HV}\right)\right]_{\max }$ と表 4 に示した表面粗さの関係を表したも のである.この図より，初期の表面硬さで無次元化した振幅 最大值 $\left[A\left(\sigma_{\mathrm{y}} / \sqrt{3} H V\right)\right]_{\max }$ がすべての試験歯車でほぼ同じ值を とっていることから, CP による硬さの増加により面圧強さ が向上したと言える.

図 8 には, 前報(11)で得られたショットピーニングを施した 浸炭硬化ローラと歯車の結果を示す．このときの損傷形態も ピッチング損傷であった. 図中の $\mathrm{R}, \mathrm{G}$ はそれぞれショット ピーニングを施してないローラおよび歯車であり，それ以外 のプロット点はショットピーニングを施した試験片を示し ている. 振幅最大值 $\left[A\left(\sigma_{y} / \sqrt{3} \mathrm{HV}\right)\right]_{\max }$ には硬さ以外の影響が現 れており, 図 8 においては未処理の試験片に比べショットピ 一ニングを施した試験片の振幅最大值 $\left[A\left(\sigma_{y} / \sqrt{3} \mathrm{HV}\right)\right]_{\max }$ が小 さくなる傾向がみられる．しかも表面粗さが大きくなるほど， 振幅最大值 $\left[A\left(\sigma_{\mathrm{y}} / \sqrt{3} \mathrm{HV}\right)\right]_{\max }$ が小さくなっていることから, シ ヨットピーニングの場合には, 鋼歯車の面圧強さに及ぼす表 面粗さの影響が顕著に現れたと判断できる.

一方，先述したように CPによる表面粗さの変化はほとん どなかったため, 図 7 より振幅最大值 $\left[A\left(\sigma_{\mathrm{y}} / \sqrt{3} \mathrm{HV}\right)\right]_{\max }$ と表面 粗さには相関関係がみられなかった。したがって, CP の場 合には, 鋼歯車の面圧強さに及ぼす表面粗さの影響はほとん どなかったと言える.

以上の結果，剛体接触がないピーニング方法という $\mathrm{CP}$ の
特徵として, 鋼歯車の面圧強さに表面粗さが影響しなかった ことが現れており，CP によるピーニング効果が直接，鋼歯 車の面圧強さ向上につながったことを明らかにした．したが って, CP は鋼歯車の面圧強さ向上に理想的な表面処理方法 であると考えられる.

\section{4. 結言}

CP を施すことにより，表面付近の硬さと圧縮残留応力が 増加し, 複雑形状の菌車に対してもピーニング効果が得られ た.一方, CP を施しても表面粗さはあまり変わらなかった. 疲れ試験の結果, 鋼ローラの疲れ寿命は CPによって向上し, 鋼歯車の面圧強さも $\mathrm{CP}$ によって向上した. $\mathrm{CP}$ による硬さの 増加が鋼歯車の面圧強さ向上につながり，面圧強さに及ぼす 表面粗さの影響がほとんどなかったことを明らかにした。

\section{謝辞}

最後に本研究の一部は, (独) 日本学術振興会 科学研究費 補助金を得て行われたことを付記する．また本研究で用いた 治具の製作にご尽力いただいた岡山大学工学部 萩原和彦技 術職員に心よりお礼を申し上げる。ささらに本研究で使用した 潤滑油を提供していただいた（株）ジャパンエナジーに謝意 を表す。

\section{文献}

(1) 加藤洋治, キャビテーション, (1999), p.3, 槇書店

(2) 文献(1)の p.199.

(3) 祖山均, 日本機械学会誌, Vol.107, No.1022 (2004), p.53.

(4) D.Odhiambo and H.Soyama, International Journal of Fatigue, Vol.25 (2003), pp.1217-1222.

(5) H.Soyama, K.Saito, M.Saka, Transactions of the ASME, Journal of Engineering Materials and Technology, Vol.124 (2004), pp.135-139.

(6) H.Soyama, Transactions of the ASME, Journal of Engineering Materials and Technology, Vol.126 (2004), pp.123-128.

(7) H.Soyama and K.Saito, Proceedings of the 7th Pacific Rim International Conference on Water Jetting Technology, (2003), pp.429-436.

(8) H.Kumano and H.Soyama, Electrochemical and Solid-State Letters, Vol.7, Iss.4 (2004), pp.G51-G52.

(9) 關正憲 - 祖山均 - 大上祐司・吉田彰, 機構論, No.06-6 (2006), pp.213-216.

(10) The Society of Materials Science, Japan, Standard Method for X-Ray Stress Measurement, (1982), p.4, The Society of Materials Science.

(11) M.Seki, A.Yoshida, Y.Ohue, et al., Journal of Advanced Mechanical Design, Systems, and Manufacturing, Vol.1, No.4 (2007), pp.518-529.

(12) 祖山均, 機構論, No.05-9 (2005), pp.361-362.

(13) 吉田彰·大上祐司·關正憲·他 3 名, 機論, Vol.68, No.668, C (2002), pp.1265-1272.

(14) K.L.Johnson, Contact Mechanics, (1987), p.84, Cambridge University Press.

(15) D.Dowson, Proceedings of the Institution of Mechanical Engineers, Vol.182, Part.3A (1967-1968), pp.151-167.

(16) P.H.Dawson, Proceedings of the Institution of Mechanical Engineers, Vol.180, Part.3B (1965-1966), pp.95-100.

(17) 關正憲・吉田彰・大上祐司, 機講論, No.04-08 (2004), pp.59-62. 